DOI: http://dx.doi.org/10.33846/hn40404

http://heanoti.com/index.php/hn

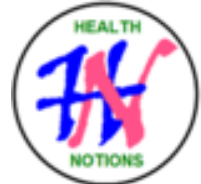

RESEARCH ARTICLE

URL of this article: http://heanoti.com/index.php/hn/article/view/hn40404

\title{
Reproductive Health of Women Workers in Villages, Cities in Islamic Perspective
}

\author{
Tri Niswati Utami ${ }^{1(\mathrm{CA})}$, Nurhayati ${ }^{2}$, Reni Agustina Harahap ${ }^{3}$, Zuhrina Aidha ${ }^{4}$ \\ ${ }^{1(\mathrm{CA})}$ Occupational Health and Safety Department, Faculty of Public Health, Universitas Islam Negeri Sumatera \\ Utara, Medan, Indonesia; triniswatiutami@uinsu.ac.id (Corresponding Author) \\ ${ }^{2}$ Islamic Economics Department, Faculty of Economics and Business in Islam, Universitas Islam Negeri \\ Sumatera Utara, Medan, Indonesia; nurhayati@uinsu.ac.id \\ ${ }^{3}$ Department of Health Promotion and Behavioral Science, Faculty of Public Health, Universitas Islam Negeri \\ Sumatera Utara, Medan, Indonesia; reniagustina@uinsu.ac.id \\ ${ }^{4}$ Department of Health Promotion and Behavioral Science, Faculty of Public Health, Universitas Islam Negeri \\ Sumatera Utara, Medan, Indonesia; zuhrinaaidha@uinsu.ac.id
}

\begin{abstract}
The trend of working women in Indonesia has increased. In 2017 the participation rate of women workers increased by $39.3 \%$. This study aims to analyze the tendency of women to work in villages and cities, analyze the relationship of women who work with reproductive health, the relationship between marital status and reproductive health and Islamic perspectives on working women. The method used was quantitative, sourced from secondary data on Indonesia's Demographic and Health Data Survey 2017 Data were analyzed using the chi-square test. It was found that the tendency of women to work in villages was higher by $65.5 \%$. The analysis found that the significant correlation between job status and marital status with reproductive health, with p-value of 0.0001 and 0.0001 . It is not forbidden in Islam that women work outside the home, but must uphold a woman's character, her role in her family and dignity. Considering women have a dual role, in the household and as workers, the company should give the right to maintain reproductive health such as menstruation leave, pregnancy, childbirth, and breastfeeding.
\end{abstract}

Keywords: female workers; types of work; reproductive health; marital status; village

\section{INTRODUCTION}

\section{Background}

Work is an activity carried out by a worker to produce goods or services. Based on statistical data for February 2018 the number of female workers increased by $0.40 \%$, which is called the Labor Force Participation Rate (LFPR), but the male LFPR decreased by $0.04 \% .{ }^{(1)}$ The safety and health of women workers need to be considered because only a few women workers have guaranteed safety, health, and reproductive rights. Workers in companies, especially women workers, receive discriminatory treatment. Legal protection such as safety, health and the rights of the reproductive system, maternity leave and menstruation leave has not been given to female workers. Law No. 13 of 2003 protects female workers to obtain menstrual leave, childbirth, and prohibition to work during pregnancy if there are indications of threatening their pregnancy. ${ }^{(2)}$ Legal protection for women workers has been investigated before, found a mismatch between regulations and legal protection. Women workers do not get the reproductive rights of menstruation leave and childbirth. The obstacle to implementing this regulation is because female workers do not know their rights. The company also intentionally violated regulations because of the company's interests. On the other hand, the government does not conduct supervision so that the regulations do not run well as result workers are harmed. ${ }^{(3)}$

Women have a dual role as a mother, wife, and role in work, for this responsibility women who work 
must be able to divide their time as well as possible. Indonesia recognizes 5 religious beliefs namely Islam, Protestantism, Catholicism, Hinduism, and Buddhism. There is no prohibition on women working according to the religion adopted in Indonesia. Likewise, Islam does not forbid women from working outside the home, so that freedom for women to work and have the same position as men. Emphasis on the role of women because women are different from men in the reproductive system, women throughout the life cycle experience changes in the reproductive system, menstruation, pregnancy, childbirth, and breastfeeding.

Worker health is affected by the work environment. The reproductive system is very sensitive, to the environment around individuals. Environments that affect reproductive health include biological, physical, cultural, behavioral and socioeconomic factors. In 2017 the number of female workforce in Indonesia was $39.3 \%$. Nationally WHO recorded an increase in the number of female workers by $0.61 \%$. ${ }^{(4)}$ The increasing number of women working can be a threat to future generations if women's reproductive health is not getting good protection. Direct impacts related to reproductive health can be seen in people who live in areas that are vulnerable to the transmission of infectious diseases such as sexually transmitted diseases. Inadequate health services can interfere with reproductive health so that pregnant women are at high risk of giving birth prematurely, birth defects and fetal death. Therefore, female workers need to pay attention to a healthy and safe work environment to avoid adverse effects on pregnancy and reproductive health.

Women are not difficult to find work because they do not choose the type of work that will be targeted to improve the family economy. For example, domestic work is dominated by women. Delgado et al., (2017) described that several female workers in Massachusetts as domestic workers found that work had an impact on physical and mental health. Daily activities carried out lifting heavy equipment, laundry, carrying gives the effect of pain in the shoulder and chronic neck. ${ }^{(5)}$ Workers in the informal sector are mostly women and do not get social protection, vulnerable to discrimination and lower wages than male workers. The number of women workers in the village is mostly in the agriculture sector. ${ }^{(6)}$ The problems that will be revealed in this study are: How do women tend to work in rural and urban areas? Is there a correlation between working women and reproductive health? Is there a correlation between marital status and reproductive health? and how does an Islamic perspective on women work?

\section{Purpose}

This study aims to find trends between working women in rural and urban areas, produce correlation between job status and marital status with reproductive health and explain the Islamic perspective on working women. Research excellence confirms that work has a positive influence on the health of the reproductive system. On the other hand, it proves the 8-hour / day work rules following ILO provisions and Law No. 13/2003 article 77 paragraph 1 in line with the Islamic view of allowing women to work and not disrupting reproductive health according to the balance cycle of the human body.

\section{METHODS}

The method used was quantitative research, sourced from secondary data Demographic and Health Data Survey for Indonesia in 2017. The survey was conducted in 33 Regencies and Cities in North Sumatra Province. Data were collected from 24 July to 30 September 2017. The population studied was a group of women of childbearing age of 15-49 years, totaling 2,545 respondents. ${ }^{(7)}$ The sample of women who worked in the village was 1274 and the sample of women who worked in the city was 1,271. Data were collected using a questionnaire, including background (age, education, occupation, media exposure), birth history, contraception, pregnancy, and postnatal examination, immunization of children (children born), children's health and nutrition, marriage and activities sexual, fertility preferences, respondent's husband/partner background, and are related to HIV / AIDS. The collected data were analyzed using descriptive statistics in the form of frequency distribution, then presented in the bar diagram. The hypothesis testing (the correlation between job status and marital status with reproductive health) were performed using Chi-square test.

\section{RESULTS}

Descriptive analysis results are shown in the figure below, it was known that the frequency distribution of women working in rural areas is higher than in urban areas. 


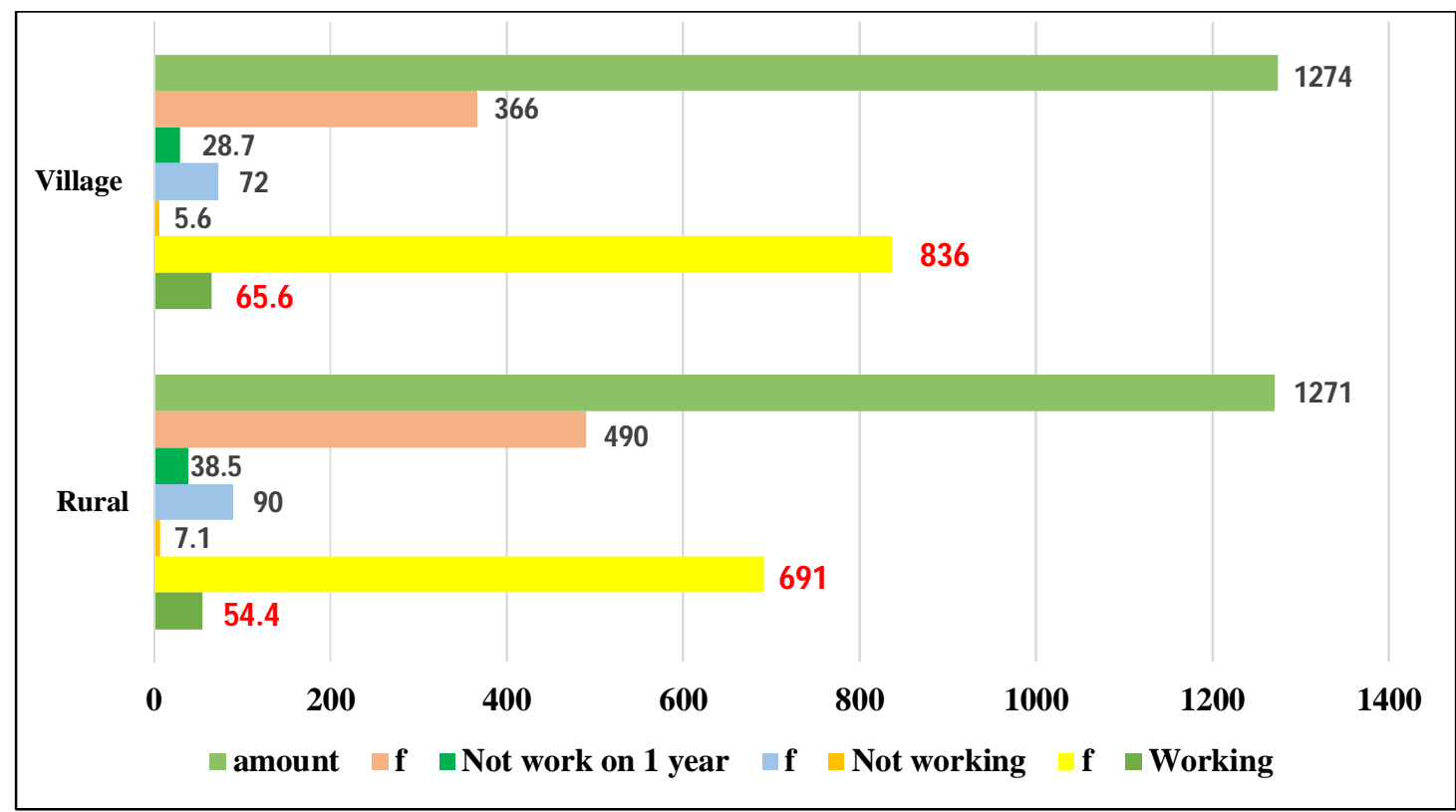

Figure 1. Distribution of Women Work

The distribution of women who worked in rural and urban areas, based on the results of there were 1274 female IDHS samples in the village and 1271 women in the city. Which then analyzed descriptively found that the frequency of women working in the village was higher by 836 people $(65.6 \%)$, not working 90 people (7.1\%), did not work in the past year 490 people (38.5\%). There were 691 women $(54.4 \%)$ working in the city, 72 people $(5.6 \%)$ unemployed and 366 people had not worked in the past year (28.7).

Table 1. The correlation between job status and reproductive health

\begin{tabular}{|c|c|c|c|c|c|c|}
\hline \multirow{3}{*}{ Job status } & \multicolumn{4}{|c|}{ Reproductive health } & \multirow[t]{2}{*}{ Total } & \multirow{3}{*}{ P-value } \\
\hline & \multicolumn{2}{|c|}{ Healthy } & \multicolumn{2}{|c|}{ Not healthy } & & \\
\hline & Frequency & Percentage & Frequency & Percentage & Total & \\
\hline Working & 35,044 & 62.2 & 16,799 & 56 & 51,843 & \\
\hline Does not work & 21,269 & 37.8 & 13,153 & 44 & 34,422 & 0.0001 \\
\hline Total & 56,313 & 100 & 29,952 & 100 & 86,265 & \\
\hline
\end{tabular}

Chi-square analysis above, that the p-value $=0.0001$ shows that there was a significant relationship between the employment status of women working with reproductive health. The percentage of women who worked with healthy reproductive status was higher by $62.2 \%$ and women who did not work with healthy reproductive status were lower by $37.8 \%$. Women who worked with unhealthy reproductive status by $56 \%$, and women who did not work unhealthy reproductive status were lower by $44 \%$.

Table 2. The correlation between between marital status and reproductive health

\begin{tabular}{|c|c|c|c|c|c|c|}
\hline \multirow[t]{3}{*}{ Marital status } & \multicolumn{4}{|c|}{ Reproductive health } & \multirow[t]{3}{*}{ Total } & \multirow[t]{3}{*}{ P-value } \\
\hline & \multicolumn{2}{|c|}{ Healthy } & \multicolumn{2}{|c|}{ Not Healthy } & & \\
\hline & Frequency & Percentage & Frequency & Percentage & & \\
\hline Never in union & 42 & 76.4 & 13 & 23.6 & 55 & \\
\hline Married & 51,898 & 64.7 & 28,318 & 35.3 & 80,216 & \\
\hline Living with partner & 322 & 55.9 & 254 & 44.1 & 576 & \\
\hline Widowed & 1852 & 67.9 & 877 & 32.1 & 2,729 & \\
\hline Divorced & 1992 & 82.3 & 428 & 17.7 & 2,420 & 0.0001 \\
\hline No longer living together/separated & 207 & 77 & 62 & 23 & 269 & \\
\hline Total & 56,313 & 65.3 & 29,952 & 34.7 & 86,265 & \\
\hline
\end{tabular}


Chi-square analysis above, that the p-value $=0.0001$ shows that there was a significant correlation between marital status in women working with reproductive health. Married status was divided into not together, married, living with a partner, widowed, divorced and not living together with a partner. A total of 86,265 respondents based on reproductive health status obtained $65.3 \%$ healthy reproductive health status and $34.6 \%$ unhealthy. The number of married women and the health status of reproductive health was greater in several $51.898(64.7 \%)$.

\section{DISCUSSION}

The study found that the percentage of female workers in rural areas was higher than female workers in cities. The phenomenon of people who live in rural areas found that the majority work in agriculture, given the still available agricultural land. On the other hand, the field of agriculture is a type of informal work, which does not require a certain level of formal education. Generally as a farm laborer cleansing fields or fields, sowing, and planting, weeding the grass, fertilizing crops or harvesting the results. The results of this study are supported by previous research, outlining that the scope of work of women at this time has been expanded, including work areas that previously only existed in men, are now also being undertaken by women.

It was further explained that women experienced role transitions in addition to playing a role in domestic life, as well as being active in improving the family economy through various activities according to their education and skills. ${ }^{(8)}$ The transition to women's work is also experienced by women in Makassar who work as construction workers, previously this work was only done by men. The motivation of women as construction workers to get a good economic status. Generally, they have arable land (gardens), because they wait for the harvest season to be used as construction workers. ${ }^{(9)}$ Women who work are divided into 2 parts, first to meet the economic needs of the family. Secondly, to achieve the desired career, so that the second category is known as career women, women who carry out activities in certain professions to achieve achievements. ${ }^{(10)}$

The Islamic perspective regulates the responsibilities of women in the family namely pregnancy, childbirth, parenting and serving her husband. This responsibility is a normal function of the human reproductive system. The characteristics of female reproductive devices and functions that are different from men, place women in a higher position than men. In addition to functioning as a sexual and hormonal tool (characterized as menstruating women), the female reproductive organs also function as the reproductive system, where the egg and sperm meet into zygotes that will develop into a fetus until the time of birth as a baby. Male and female reproductive health is affected by various conditions in the surrounding environment such as the work environment, home environment, and social environment.

Reproductive health according to WHO (2012) is interpreted as individuals who can reproduce safely and satisfactorily. Women's reproductive health determines the health of the generation born. Women who work in both the formal and informal sectors must understand the risks of occupational hazards to their reproductive health. Special protection is given to female workers, pregnant, breastfeeding, because the effects of work can have an impact on child development. Recommendations that can be given are modifications to the supply of personal protective equipment. However, management must still strive to provide reproductive health protection without discriminating against sex. ${ }^{(11)}$

Verbiest (2016) states that collaboration and advocacy between sectors are needed to achieve optimal reproductive health for both men and women. The preparation starts from childhood to adulthood and works, involving social institutions, government, health sector, labor department, social workers and interfaith to produce local and national policies. ${ }^{(12)}$ The role of mothers in implementing reproductive health education is needed for children, especially in childhood. Open communication, the introduction of the reproductive system and teaches the cleanliness of the reproductive system with religious and cultural approaches in the family more easily accepted and understood by children. Some countries have different ways and traditions regarding the view of reproductive health. In Pakistan, communication between mothers and children about reproduction is still taboo, and there is no difference between educated and uneducated mothers. ${ }^{(13)}$

First research findings: Development of the concept of occupational health with reproductive systems and Islamic integration. The relationship between working women and the types of work on reproductive health is very close. The role of women is regulated in Islam, and this role is related to the reproductive system. This finding is supported by previous research, women following their responsibilities to carry out the role of wife and mother for the family. ${ }^{(14)}$ Pregnancy, childbirth, breastfeeding and educating children are functions of the reproductive system. Islam does not forbid women from working, because work is a way to achieve God's blessing. Solihatin (2017) gives the opinion that work is a virtue allowed for women and men, to achieve a good quality of life. ${ }^{(15)}$

The increasing number of women workers in various formal and informal work sectors shows that the involvement of women in work contributes to the family and society, women acting as productive societies that support the family economy. Women are not only responsible for looking after the family but have been involved in the world of work. Miko (2015) through descriptive case study research in Subulussalam City stated 
that some of the reasons women work to earn a living are due to low husband's income, increased living necessities, the cost of education and dependents of large children, as well as encouragement to get a more decent life. ${ }^{(16)}$ The majority of jobs chosen are trading. Second research findings. The status of working and married women is positively related to reproductive health. Someone married will become healthier, forming high motivation for the couple and the future. Physiologically the hormone oxytocin produced by the brain is influenced by the female reproductive system.

\section{CONCLUSION}

The tendency of women to work in rural areas is higher than in cities because agricultural land is still available. Jobs in agriculture do not require certain levels of education. Women act as productive societies to support the family economy. Working women and married status are positively related to reproductive health. Women who are married will more often release the hormone oxytocin which is influenced by the reproductive system. Islamic perspective allows women to work, as a way of worship to get the blessing of Allah.

It is recommended for women who work to always maintain health and not leave family responsibilities. Employers who employ women to give rights and not be discriminating against. The government can draw up regulations for formal and informal women workers, monitor employers who employ women so that women's reproductive health can be maintained.

\section{REFERENCES}

1. BPS. Indonesian Employment Conditions (Keadaaan Ketenagakerjaan Indonesia). Jakarta: Badan Pusat Statistik; 2018.

2. RI. Law of the Republic of Indonesia Number 13 of 2003 concerning Manpower (Undang-Undang Republik Indonesia Nomor 13 Tahun 2003 tentang Ketenagakerjaan Employment). Jakarta; The Republic of Indonesia; 2003.

3. Djakaria M. Legal Protection for Women Workers to Obtain Workers' Rights Associated with Reproductive Health (Perlindungan Hukum Bagi Pekerja Wanita untuk Memperoleh Hak-Hak Pekerja dikaitkan dengan Kesehatan Reproduksi). J Bina Mulia Huk. 2018;3(1):1-14.

4. WHO. Percentage of Women in the Global Databoks Workforce [Internet]. Geneva: World Health Organization; 2018. Available from: https://databoks.katadata.co.id/datapublish/2018/10/10/iw_femalelabour-participation-by-year

5. Delgado D, Morris JE, Bravo D, Nguyen M, Gottlieb B. The Health Impacts of Domestic Labor on Women Workers in Massachusetts. Theory in Action. 2017;10(2):21-40.

6. Zuhdi S. Discusses the Dual Role of Women in Industrial Society (Membincang Peran Ganda Perempuan Dalam Masyarakat Industri). J Huk Jurisprud. 2018;8(2):81-6.

7. BKKBN. Indonesian Demographic and Health Survey 2017 (Survei Demografi dan Kesehatan Indonesia 2017). Susilo P, Dwiana A, editors. Jakarta: BKKBN; 2018.

8. Majid F. Factors that Influence the Decision of Married Women to Work Case Study: Semarang City (Faktor-Faktor yang Mempengaruhi Keputusan Perempuan Berstatus Menikah Untuk Bekerja, Studi Kasus: Kota Semarang). Semarang: Universitas Diponegoro; 2012.

9. Rahmatiah. At a Glance Women's Building Workers in Makassar City (Selayang Pandang Buruh Bangunan Perempuan di Kota Makassar). J Sosiol Dialetika Kontemporer. 2014;2(1):8-16.

10. Asriaty. Career Women in Islamic View (Wanita Karir dalam Pandangan Islam). J Al-Maiyyah. 2014;07(2):166-89.

11. Bliss MM, Krzystowczyk J. Inclusive and Gender: Protecting Workers' Reproductive Health. Prof Saf. 2018;63(03):38-43.

12. Verbiest S, Malin CK, Drummonds M, Kotelchuck M. Catalyzing a Reproductive Health and Social Justice Movement. Matern Child Health J. 2016;20(4):741-8.

13. Yasin SA, Shahed S, Iqbal T. Effects of Mother-Daughter Communication on Reproductive Health in Pakistani Society. Pakistan J Women's Stud Alam-e-Niswan [Internet]. 2013;20(2):81-98. Available from: http://turing.library.northwestern.edu/login?url=http://search.proquest.com/docview/1522269186?accounti $\mathrm{d}=12861 \% 5 \mathrm{Cnhttp} / /$ hopper.library.northwestern.edu/sfx?genre=article\&sid=ProQ:\&atitle=EFFECTS+OF +MOTHER-DAUGHTER+COMMUNICATION+ON+REPRODUCTIVE+HEALTH+IN+

14. Rusli M. Women's Career Perspective of Islamic Law; Case Study in Rappocini District, Makassar City (Wanita Karir Persfektif Hukum Islam; Studi Kasus di Kecamatan Rappocini Kota Makassar) [Internet]. Makassar: Universitas Islam negeri ALauddin Makassar (UINAM); 2016. Available from: http://repositori.uin-alauddin.ac.id/2223/

15. Solihatin IR. Quranic Conception of Women Workers in Family Welfare (Konsepsi Al Quran tentang Perempuan Pekerja dalam Mensejahterakan Keluarga). HARKAT Media Komun Islam tentang Gend dan 
Anak. 2017;12(2):78-91.

16. Miko J. The Role of Women as Main Livelihood Seekers in Subulussalam City: Phenomenology Study (Peran Perempuan sebagai Pencari Nafkah Utama di Kota Subulussalam: Studi Fenomenologi). Medan: Universitas Islam Negeri Sumatera Utara; 2016. 